\title{
A MULTIDISCIPLINARY INVESTIGATION AT THE LASTROS-SFAKA GRABEN, CRETE
}

\section{Mason J. 1, Schneiderwind S. ${ }^{1}$, Pallikarakis A. ${ }^{2}$, Wiatr T. 1,a, Mechernich S. ${ }^{3}$, Papanikolaou I. ${ }^{2}$ and Reicherter K. ${ }^{1}$}

\author{
${ }^{1}$ RWTH Aachen University, Institute of Neotectonics and Natural Hazards, Lochnerstr, 4-20, \\ 52056 Aachen, Germany, j.mason@nug.rwth-aachen.de \\ ${ }^{2}$ Laboratory of Mineralogy \& Geology, Department of Natural Resources Development and \\ Agricultural Engineering, Agricultural University of Athens, 75 Iera Odos Str., 11855 Athens, \\ Greece \\ ${ }^{3}$ Institut für Geologie und Mineralogie, Universität zu Köln, Greinstraße 4, 50939 Köln, Germany \\ ${ }^{a}$ now at: Federal Agency for Cartography and Geodesy, Frankfurt, Germany
}

\begin{abstract}
Results from a multidisciplinary investigation at the Lastros-Sfaka Graben located in eastern Crete are presented. $1.3 \mathrm{~km}$ of the Lastros fault was scanned with t-LiDAR and we identified areas with minor external influences (anthropogenic, depositional or erosional) to extract throw rates. Preliminary postglacial throw rates are $0.67 \pm$ $0.15 \mathrm{~mm} / \mathrm{yr}$., which is significantly less than stated in the literature. Cemented colluvium is located on the Lastros fault, forming hanging-wall talus lobes and sheets of varying thickness attached to the fault plane. Stable isotope analysis on the cement indicates that it has a meteoric origin and precipitated from water at temperatures between 5 and $8^{\circ} \mathrm{C}$. Field mapping and GPR shows that cemented colluvium, is also present within the hanging-wall subsurface. Trenching (road cut) investigations on the Sfaka fault identified fill material most likely deposited soon after the last palaeoearthquakes that occurred on the fault; ${ }^{14} \mathrm{C}$ dating is currently being carried out to date this fill material.
\end{abstract}

Keywords: bedrock fault scarps, $t$-LiDAR, cemented colluvium, GPR, fissure fill.

\section{Пєрі́ $\eta \psi \eta$}

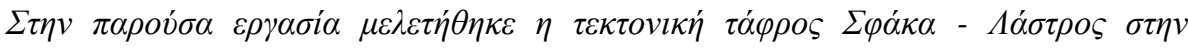

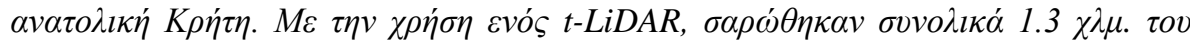

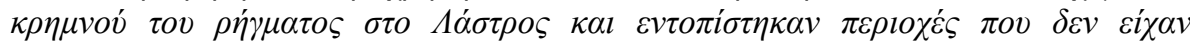

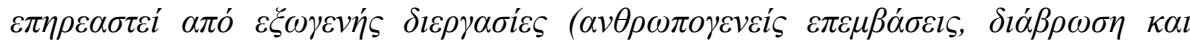

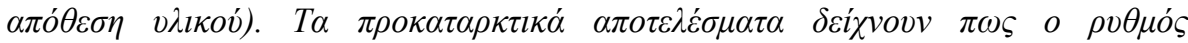

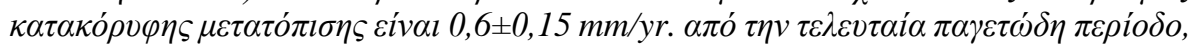

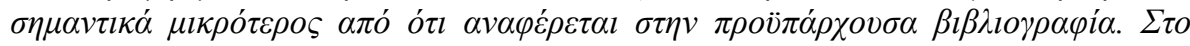

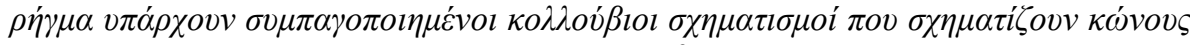

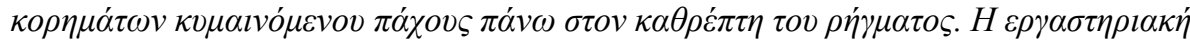

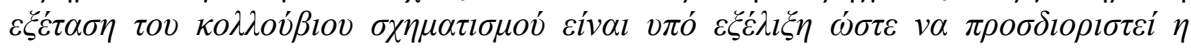


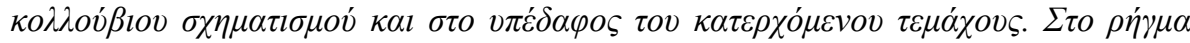

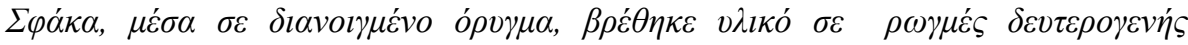




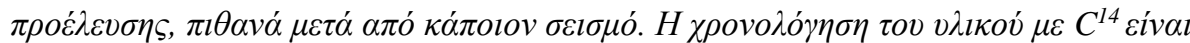
vлó $\varepsilon \xi \varepsilon^{\prime} \lambda l \xi \eta$.

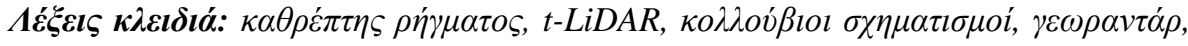
$\delta \varepsilon v \tau \varepsilon \rho о \gamma \varepsilon v \dot{\varsigma} \varsigma$ viкó $\sigma \varepsilon \rho \omega \gamma \mu \varepsilon \dot{\varsigma}$.

\section{Introduction}

The active extensional regime of the Aegean has produced many normal faults throughout the region. On the island of Crete (Fig. 1), many of these normal faults comprise footwall limestone bedrock scarps which are mainly juxtaposed against hanging-wall Quaternary colluvial and/or marine sediments, forming prominent features within the mountainous landscape. The preserved fault scarps (Fig. 2) are most likely postglacial (as described on mainland Greece by Benedetti et al., 2002; Papanikolaou et al., 2005) and result from cumulative earthquake events on the individual fault plane. These faults are considered to be capable; a capable fault is defined as a fault that has significant potential to cause displacement at or near the ground surface (IAEA, 2010). There are over 20 known bedrock normal faults/fault segments (Caputo et al., 2010) located throughout Crete (Fig. 1) which are considered to be capable and have large exposed bedrock fault scarps.

This paper presents the preliminary results of a multidisciplinary investigation at the Lastros-Sfaka Graben located within the Ierapetra Fault Zone (IFZ), eastern Crete (Fig. 1). The Graben consists of two opposing faults - the Lastros fault and the Sfaka fault (Figs. 1 and 2). Both these faults strike approximately NNE - SSW and have prominent limestone fault scarps. The Quaternary hangingwall colluvium of these faults mainly comprises unconsolidated material that has fallen from the footwall mountain above the scarp; in various locations this colluvium has become cemented. To date there have been no investigations into this phenomenon. Various methods including geological mapping, trenching (road cuts), terrestrial Light Detection And Ranging (t-LiDAR), and ground penetrating radar (GPR) were used on the footwalls and hanging-walls of these faults. Laboratory analyses including thin section analyses, stable isotope and ${ }^{14} \mathrm{C}$ dating are ongoing.

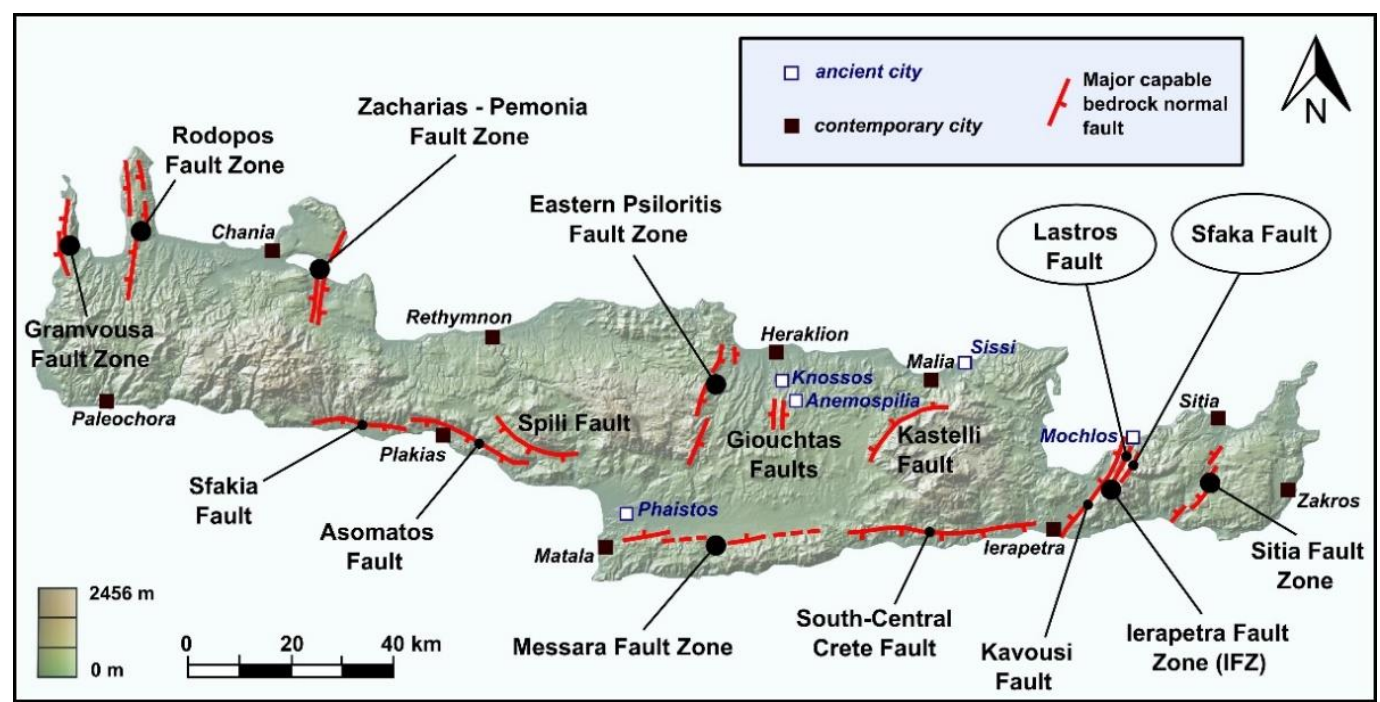

Figure 1 - Relief map of Crete showing the locations of the major capable bedrock faults and fault zones throughout the island (fault locations from Caputo et al., 2010; Gallen et al., 2014). 


\section{Seismotectonic setting}

Crete has been designated as having a high seismic risk due to the island's location close to the Hellenic Arc and Trench System (LePichon and Angelier, 1979; Armijo et al., 1992; Jolivet et al., 2013). The island has a long record of destructive earthquakes with countless historical reports of damage and destruction (Papadopoulos, 2011; Papazachos and Papazachou, 1997). Throughout the Aegean, crustal back arc extension is occurring and interpreted as a response to the southward slabrollback of the Hellenic margin, the southwestward expulsion of the Aegean microplate and the anticlockwise rotation of the African lithosphere relative to Eurasia (Meulenkamp et al., 1988). The deformation history of geological units within Crete can be summarised as: (i) compressional deformation producing arc-parallel east-west-trending south-directed thrust faults in the Oligocene to Early Miocene; (ii) extensional deformation along arc-parallel, east-west-trending detachment faults in Middle Miocene time, with hanging-wall motion to the north and south; and (iii) Late Miocene-Quaternary transtensional deformation along high-angle normal and oblique normal faults that disrupt the older arc-parallel structures (Papanikolaou and Vassilakis, 2010). The study area is the Lastros-Sfaka Graben located in eastern Crete and forms part of the Ierapetra Fault Zone (IFZ; Fig. 1) which consists of a roughly $25 \mathrm{~km}$ long zone of faults segments (Gaki-Papanastassiou et al., 2009).

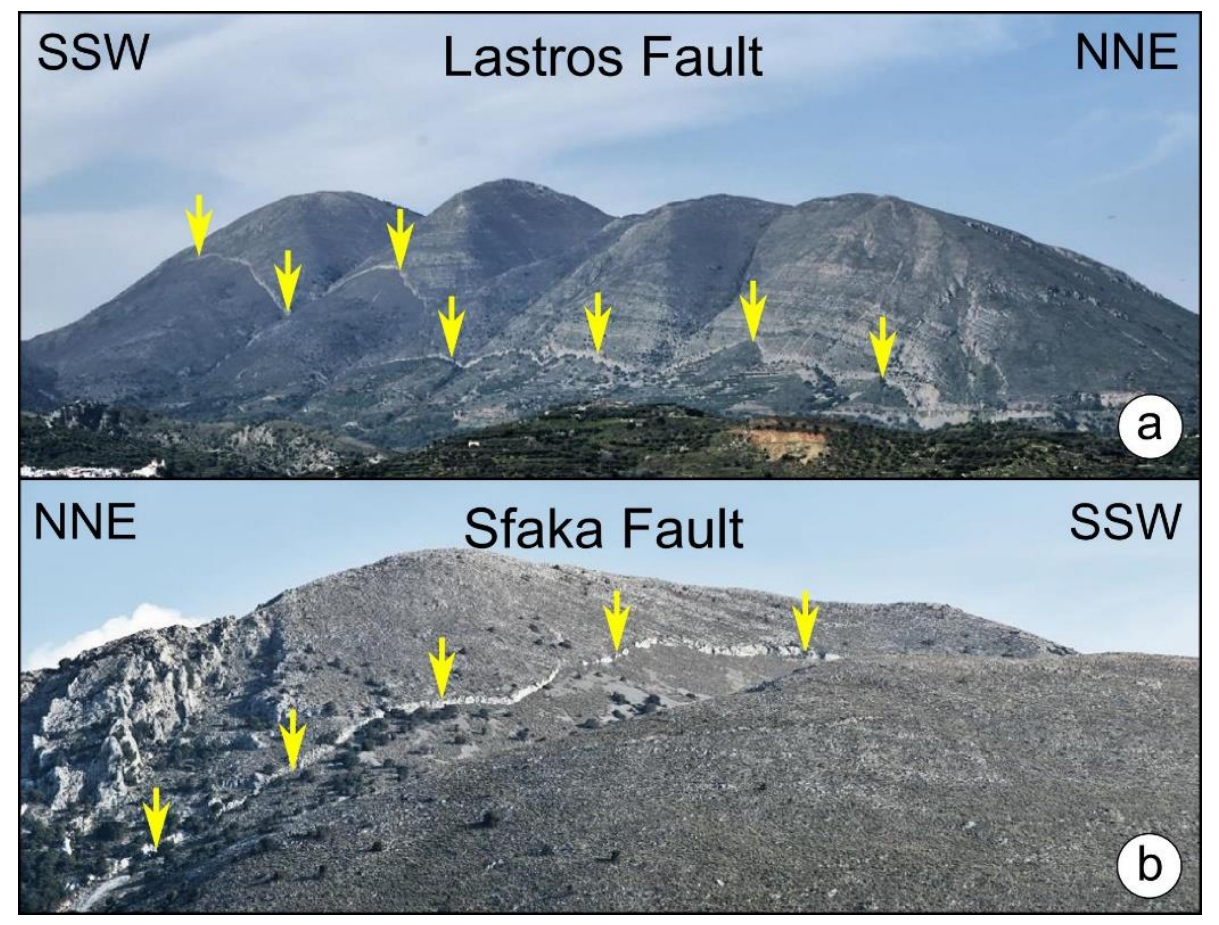

Figure 2 - a) View of the Lastros Fault; b) View of the upper segment of the Sfaka Fault.

\section{The Lastros Fault}

The Lastros fault is located on the western side of the Graben and strikes NNE-SSW $\left(020^{\circ}-200^{\circ}\right)$. The fault comprises two segments separated by a step over; in the south the fault steps back into the footwall by around $300 \mathrm{~m}$ (Fig. 2a). Manual measurements show that the upper segment in the south has an average dip angle of c. $70^{\circ}$ and the lower northern segment has an average dip angle of c. $65^{\circ}$. A clear bedrock fault plane was mapped for approx. $5 \mathrm{~km}$.

In many places along strike the hanging-wall colluvium, which is mostly loose material that has fallen from the footwall mountain above the scarp and settled on the hanging-wall, has become 
cemented (Fig.3). This cemented colluvium can be described as a breccia/conglomerate with subrounded to angular clasts (implying short transport distances) in a relatively hard, carbonate matrix. The cemented colluvium forms different geomorphological structures: a large talus lobe is located towards the northern end of the fault (Figs. 3a, 4), and at many locations along strike the cemented colluvium forms sheets or slices orientated parallel to the fault plane ranging in thickness from decimetres to several metres (Fig. 3b,c).
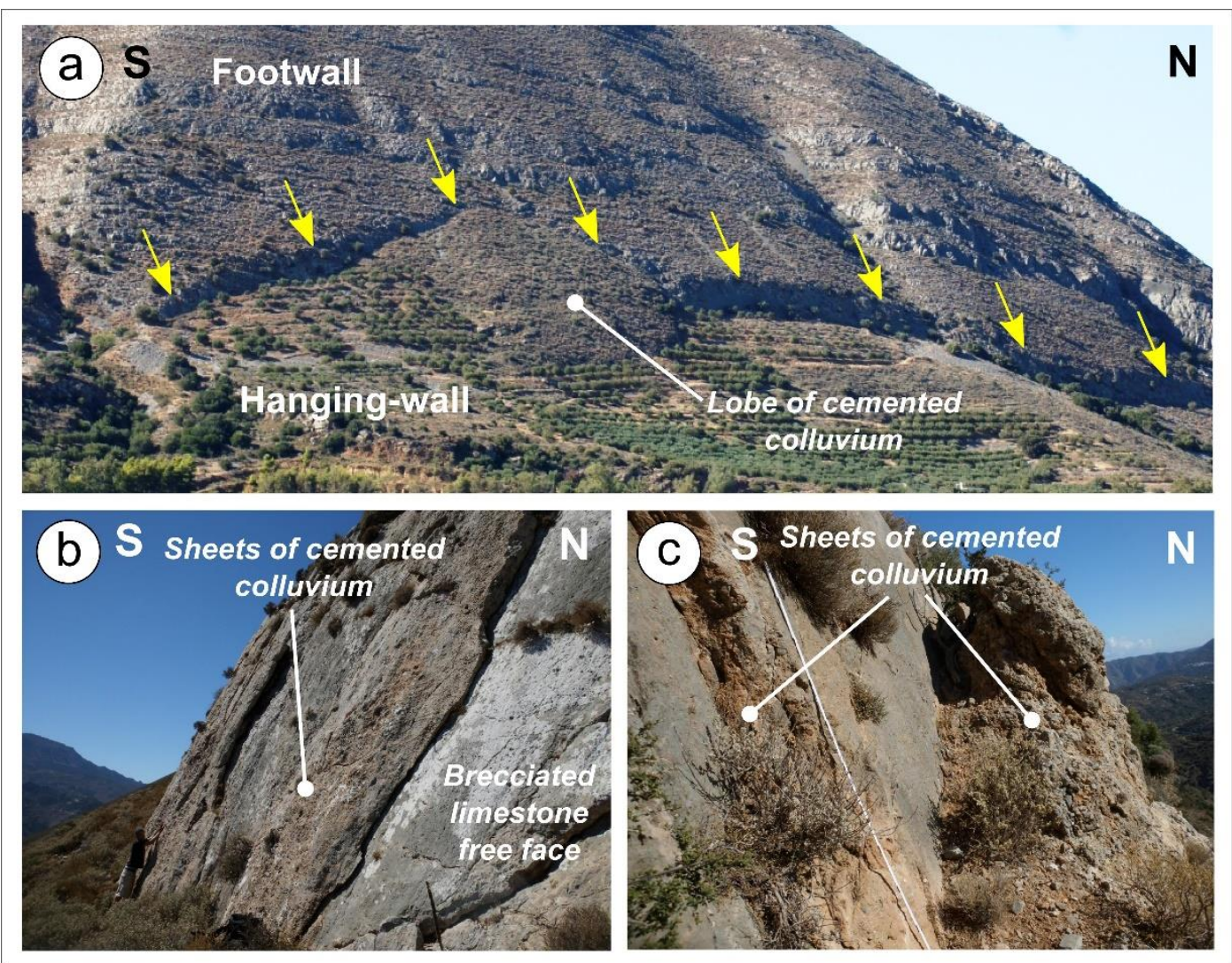

Figure 3 - a) View of the Lastros Fault (yellow arrows) showing the Lobe of hanging-wall cemented colluvium; b) sheets of cemented colluvium up to $40 \mathrm{~cm}$ thick; c) sheets of cemented colluvium up to $80 \mathrm{~cm}$ thick.

\subsection{Methods and Results}

t-LiDAR was undertaken on approximately $1.3 \mathrm{~km}$ of the lower segment of the fault. This was done to accurately calculate scarp heights which can then be used to infer post glacial throw rates (e.g. Papanikolaou et al., 2005). The point clouds from 12 scan windows were combined and georeferenced using GPS data taken in the field and converted into a $1 \times 1 \mathrm{~m}$ resolution raster format in GIS. The t-LiDAR derived digital elevation model (DEM) showing slope angle is shown in figure 4. The DEM clearly shows man made terraces within the hanging-wall and large catchment gullies cutting the fault. Throw calculations show maximum projected throws (Papanikolaou et al., 2005) of around $10 \mathrm{~m}$ in areas where there is little evidence of anthropogenic activity, erosion, or sedimentation. 


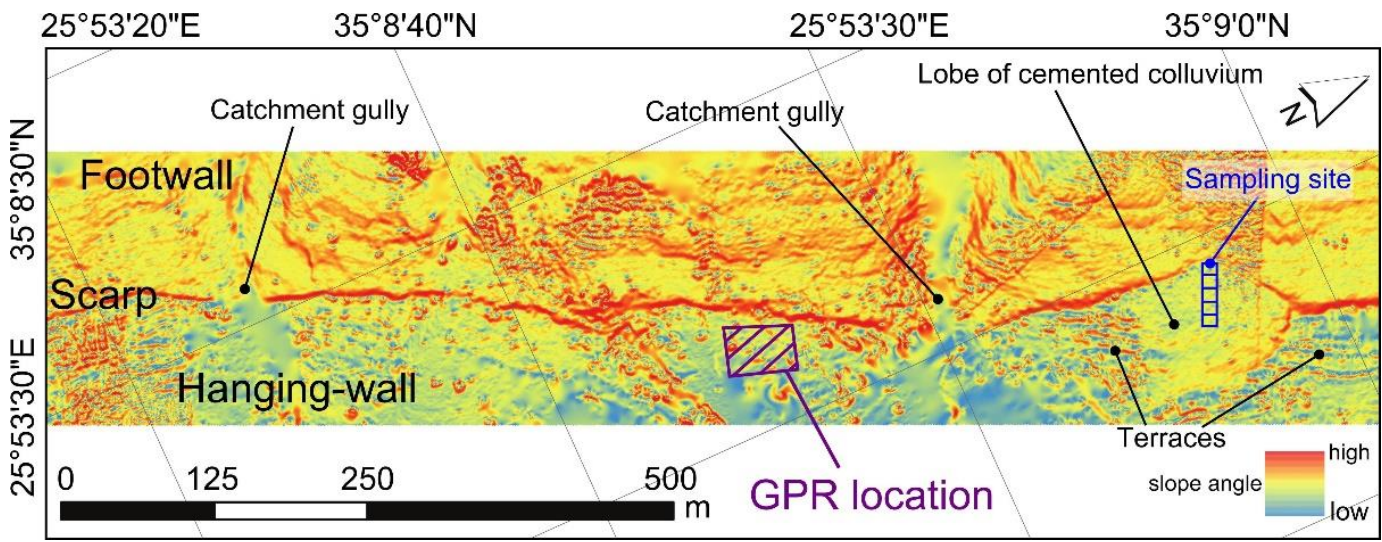

Figure 4 - t-LiDAR scan of $1.3 \mathrm{~km}$ of the lower segment of the Lastros fault showing slope angle. Note the gullies and the terraces in the hanging-wall; long term throw rate calculation should not be undertaken at or near these locations.

The cemented colluvial lobe at the northern end of the fault (Fig. 3a) was sampled every $5 \mathrm{~m}$ from the fault scarp (see Fig. 4 for location). This was done to determine the composition of the cement and also whether the cemented colluvium changes with distance from the scarp. The cement is predominantly calcite containing varying amounts of mud/clay. Stable isotope analysis of $\delta^{13} \mathrm{C}$ and $\delta^{18} \mathrm{O}$ indicate that the source water has a meteoric origin and the deposit can be classified as a meteogene. The average $\delta^{13} \mathrm{C}$ value for all three facies is $-7.95 \%$ which falls within the typical range for meteogenes (Pentecost, 2005). Palaeotemperature calculations based on the equations of Hays and Grossman (1991) show parent water precipitation temperatures ranging from 5 to $8^{\circ} \mathrm{C}$. As groundwater temperatures are generally equal to the average annual air temperature above the land surface, the palaeotemperature results indicate a significantly cooler climate at the time of precipitation compared to present day temperatures.

To determine whether the cemented colluvium was present in the hanging-wall subsurface, GPR was also undertaken. GPR profiles were carried out perpendicular to strike (for location see Fig. 4). The profiles show a number different radar facies (Neal, 2004) within the hanging-wall subsurface. The very low reflectance properties of one of these radar facies compared to the surrounding material (Fig. 5), its geometry and its continuity in multiple profiles leads us to infer cemented colluvium buried in the hanging-wall shallow subsurface.

\section{The Sfaka Fault}

The Sfaka fault (Figs. 1, 2b) is located on the eastern side of the Graben. It strikes at NNE-SSE $\left(020^{\circ}\right.$ $\left.-200^{\circ}\right)$ and is antithetic to the Lastros fault. The Sfaka fault was mapped for approx. $5 \mathrm{~km}$ and the fault plane has an average dip of $63^{\circ}$. The Sfaka fault also comprises two segments separated by a step over; in the south the fault steps approx. $500 \mathrm{~m}$ to the west into the hanging-wall. The footwall of the fault comprises crystalline limestone, and the hanging-wall also comprises this limestone often overlain by colluvium; only in the north of the upper segment are phyllites present in the hangingwall, which are again overlain by colluvium.

During mapping of the northern part of the upper segment, we followed the Sfaka fault along a narrow valley in which a dirt road has been constructed to access nearby olive groves. Here the dirt road cuts the fault plane at two locations, one approximately $40 \mathrm{~m}$ from the other. These two road cuts are essentially acting like vertical shallow angle trenches opened approximately $70^{\circ}$ from the fault's strike. Here we briefly present some preliminary results from the lower road cut, herein referred to as Trench 2 . 


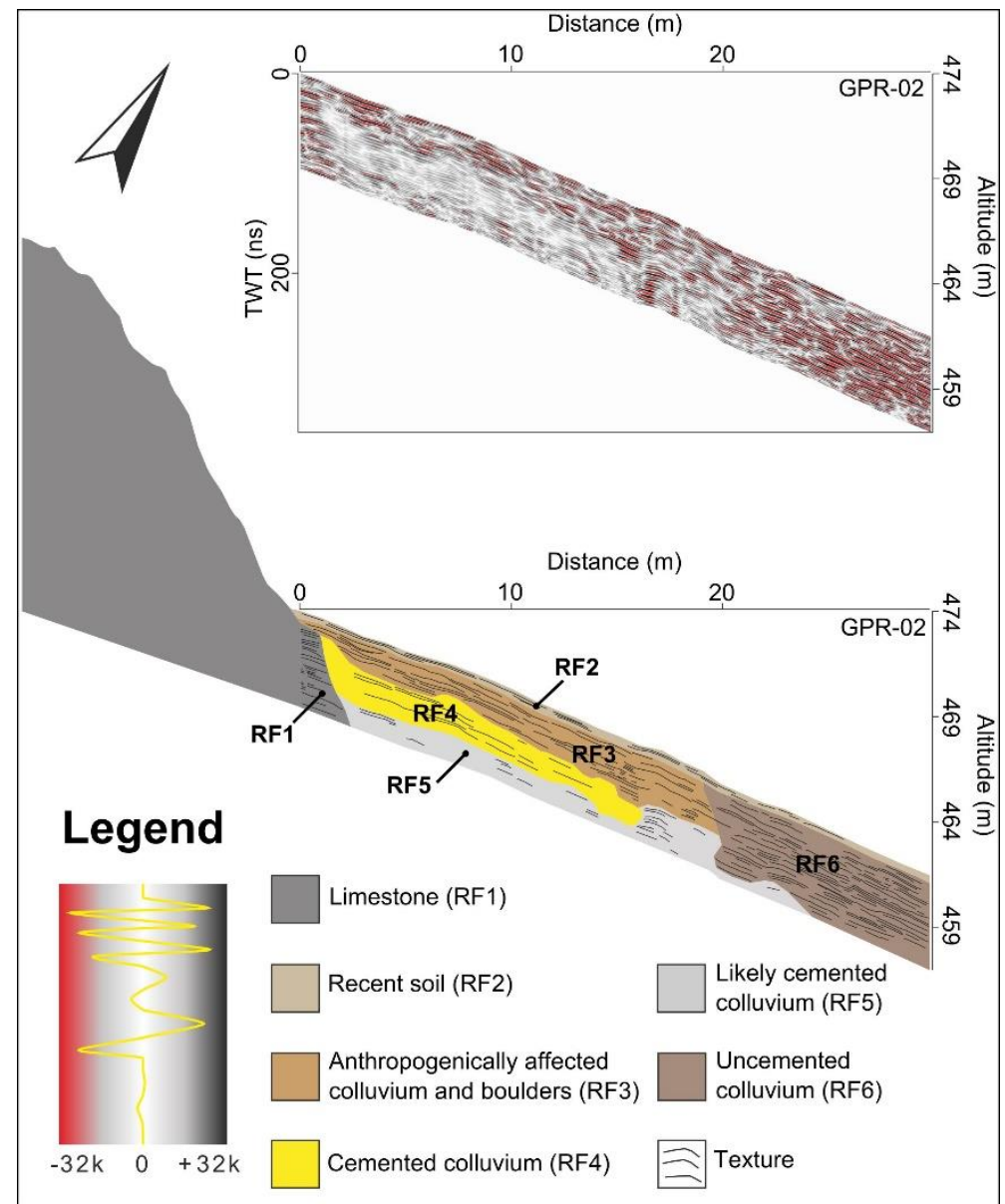

Figure 5 - Uninterpreted and interpreted GPR profile at the Lastros fault showing cemented colluvium present in the subsurface.

\subsection{Methods and Results}

At Trench 2 the exposure was cleaned of vegetation and the outermost $10-15 \mathrm{~cm}$ of soil and gravel. The trench was logged and photographed and samples were taken from identified displaced layers and other horizons for subsequent classification analyses. Trench 2 (Fig. 6a, b) shows fissure fill material located between the fault gouge and the colluvial layers. The fissure fill material has both a high amount of fines and gravel. The fill is most likely not scarp derived but from palaeosols that developed on the surface of the hanging-wall. Orientated clasts at the boundary between the fill and the fault gouge are further evidence for a tectonic origin. The fissure fill material has been sampled for ${ }^{14} \mathrm{C}$ dating which is ongoing. Within the hanging-wall there are a number of small displacement antithetic faults that have developed within the colluvial gravels, which are typical of extension in unconsolidated sediments. Cemented colluvium is also present in the trench beginning c. $6 \mathrm{~m}$ from the fault scarp.

\section{Discussion and Conclusions}

Previous work has been carried out on the Lastros and Sfaka faults by Caputo et al. $(2006,2010)$. The authors calculated long-term slip rates for both the Lastros and Sfaka faults based on scarp heights and a $13 \mathrm{ka}$ (post glacial) date for first exhumation. The authors estimated a slip rate of 1.3 $\mathrm{mm} / \mathrm{yr}$ for the Lastros fault using a maximum throws of $15 \mathrm{~m}$. However, our preliminary t-LiDAR 
results show that the maximum throw is around $10 \mathrm{~m}$ when measurements are undertaken in areas not influenced by anthropogenic activity and erosion. When using a $13 \mathrm{ka}$ post exhumation date the estimated throw rate is $0.8 \mathrm{~mm} / \mathrm{yr}$ for a scarp with $10 \mathrm{~m}$ of throw. However, there is no evidence for $13 \mathrm{ka}$ representing the change from glacial to post-glacial conditions. $15 \pm 3 \mathrm{ka}$ is more commonly used for throw rate estimations (e.g. Papanikolaou et al., 2012). This $15 \pm 3$ ka range comes from research in Italy and is due to the uncertainty on the exact post-glacial age estimate; $18 \mathrm{ka}$ is the initiation of the last glacial retreat (Allen et al., 1999) that dominates the present geomorphology of the region, and $12 \mathrm{ka}$ is the youngest reported age in the literature since some small magnitude glacial re-advances followed by retreat phases have been recorded between 12 and $18 \mathrm{ka}$, predominantly between 14 and $18 \mathrm{ka}$ (e.g. Giraudi and Frezzotti, 1997). Therefore using a $10 \mathrm{~m}$ throw and $15 \pm 3 \mathrm{ka}$ for first exhumation, a throw rate of $0.67 \pm 0.15 \mathrm{~mm} / \mathrm{yr}$ is produced for the Lastros fault.
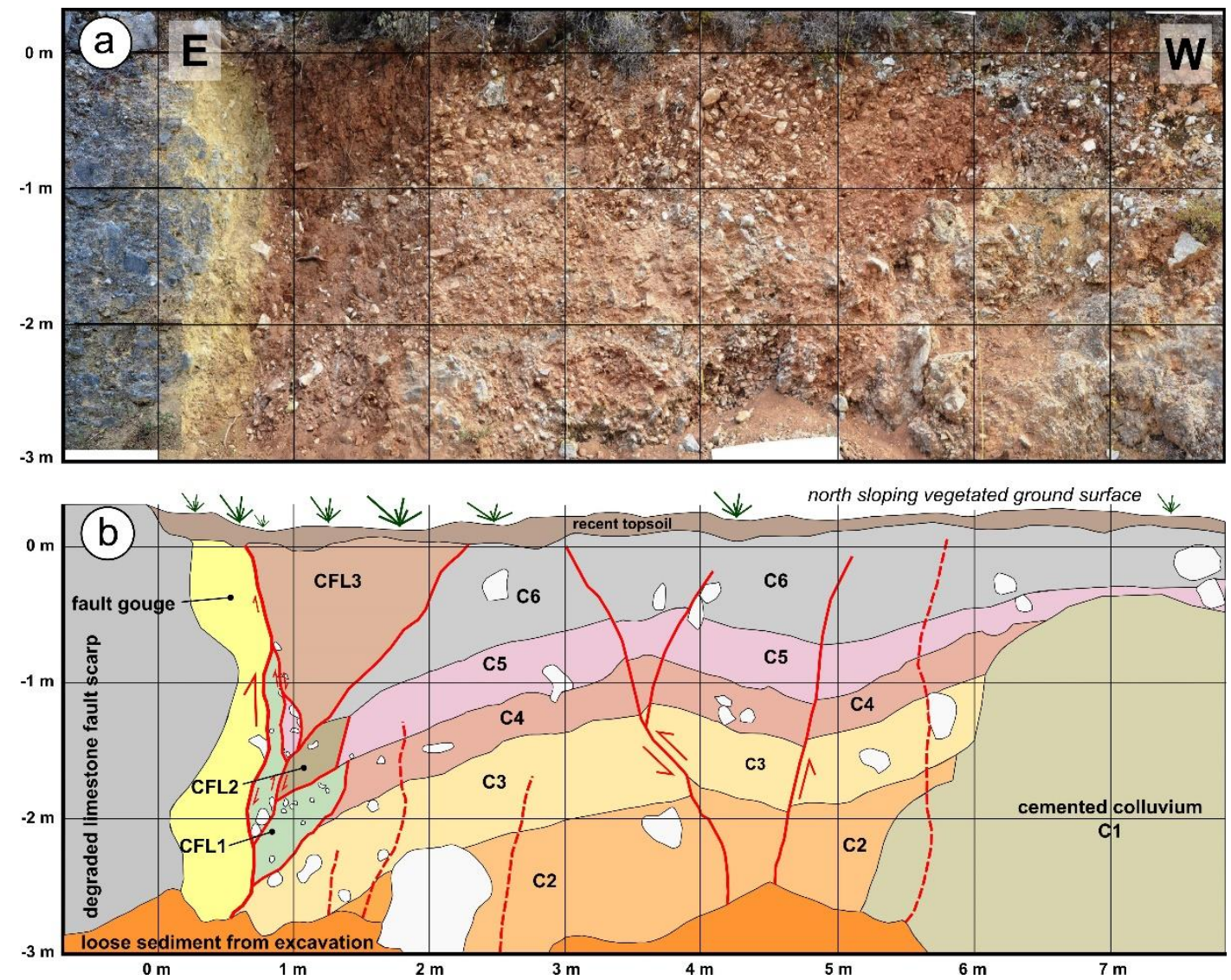

Figure 6 - a) Photomosaic of Trench 2 at the Sfaka Fault; b) Trench 2 log interpretation, CFL indicates crack fill material, C2 - C6 represent uncemented colluvial layers, C1 represents cemented colluvium.

Further work on the t-LiDAR DEM will determine whether more representative areas can be found for throw rate calculations. Work will also continue on the Sfaka fault to determine if the throw rate of $1.0 \mathrm{~mm} / \mathrm{yr}$. (Caputo et al., 2010) can be confirmed by our studies. This was calculated using a 12 $\mathrm{m}$ scarp height, and from initial observations in the field, scarps of this height are heavily influenced by erosion. The dating of the fissure fills and trench retrodeformation will produce a recurrence interval for the Sfaka fault. As the Sfaka fault is antithetic to the Lastros fault, the possibility that fissure fills represent slip from accommodation events rather than seismogenic ruptures must be considered. 


\section{Acknowledgements}

The authors would like to thank Alex Woywode, Tobias Baumeister, and Lauretta Kearger for the help in the field. We also thank Manolis from the Zorbas Taverna in Pachia Ammos for the loan of the generator and his great hospitality.

\section{References}

Allen, J.R.M., Brandt, U., Brauer, A., Hubberten, H.W., Huntley, B., Keller, J., Kraml, M., Mackensen, A., Mingram, J., Negendank, J.F.W., Nowaczyk, N.R., Oberhansli, H., Watts, W.A., Wulf, S. and Zolitschka, B., 1999. Rapid environmental changes in southern Europe during the last glacial period, Nature, 400, 740-743.

Armijo, R., Lyoncaen, H. and Papanastassiou, D., 1992. East-west extension and Holocene normalfault scarps in the Hellenic arc, Geology, 20, 491-494.

Benedetti, L., Finkel, R., Papanastassiou, D., King, G., Armijo, R., Ryerson, F., Farber, D. and Flerit, F., 2002. Post-glacial slip history of the Sparta fault (Greece) determined by $36 \mathrm{Cl}$ cosmogenic dating: Evidence for non-periodic earthquakes, Geophys. Res. Lett., 29, 1246.

Caputo, R., Monaco, C. and Tortorici, L., 2006. Multiseismic cycle deformation rates from Holocene normal fault scarps on Crete (Greece), Terra Nova, 18(3), 181-190.

Caputo, R., Catalano, S., Monaco, C., Romagnoli, R., Tortorici, G. and Tortorici, L., 2010. Active faulting on the island of Crete (Greece), Geophys. J. Int., 183, 111-126.

Fountoulis, I. and Mariolakos, I., 2008. Neotectonic folds in the central-western Peloponnese, Greece, Zeitschrift der Deutschen Gesellschaft fur Geowissenschaften, 159/3 485-494.

Gaki-Papanastassiou, K., Karymbalis, E., Papanastassiou, D. and Maroukian, H., 2009. Quaternary marine terraces as indicators of neotectonic activity of the Ierapetra normal fault SE Crete (Greece), Geomorphology, 104, 38-46.

Gallen, S.F., Wegmann, K.W., Bohnenstiehl, D.R., Pazzaglia, F.J., Brandon, M.T. and Fassoulas, C., 2014. Active simultaneous uplift and margin-normal extension in a forearc high, Crete, Greece, Earth and Planetary Science Letters, 398, 11-24.

Giraudi, C. and Frezzotti, M., 1997. Late Pleistocene glacial events in the central Apennines, Italy, Quaternary Research, 48, 280-290.

Hays, P. and Grossman, E., 1991. Oxygen isotopes in meteoric calcite cements as indicators of continental paleoclimate, Geology, 19, 441-444.

International Atomic Energy Agency (IAEA), 2010. Seismic Hazards in Site Evaluation for Nuclear Installations. Specific Safety Guide No. SSG-9.

Jolivet, L., Faccenna, C., Huet, B., Labrousse, L. and Le Pourhiet, L., 2013. Aegean tectonics: Strain localisation, slab tearing and trench retreat, Tectonophysics, 597-598.

LePichon, X. and Angelier, J., 1979. The Hellenic Arch and Trench System: A key to the neotectonic evolution of the Eastern Mediterranean area, Tectonophysics, 60, 1-42.

McCalpin, J.P., 2009. Paleoseismology, Elsevier, 2nd edition, 613 pp.

Meulenkamp, J.E., Wortel, M.J.R., Van Wamel, W.A., Spakman, W. and Hoogerduyn Strating, E., 1988. On the Hellenic subduction zone and the geodynamic evolution of Crete since the late Middle Miocene, Tectonophysics, 146, 203-215.

Neal, A., 2004. Ground-penetrating radar and its use in sedimentology: principles, problems and progress, Earth Science Reviews, 66, 261-330.

Papadopoulos, G., 2011. A Seismic History of Crete. The Hellenic Arc and Trench. Earthquake and Tsunamis: 2000 BC - 2011 AD. Ocelotos Publications, 415 pp.

Papanikolaou, D. and Vassilakis, E., 2010. Thrust faults and extensional detachment faults in Cretan tectonostratigraphy: implications for Middle Miocene extension, Tectonophysics, 488, 233-247.

Papanikolaou, I., Roberts, G. and Michetti, A., 2005. Fault scarps and deformation rates in LazioAbruzzo, Central Italy: comparison between geological fault slip-rate and GPS data, Tectonophysics, 408, 147-176. 
Papanikolaou, I., Roberts, G., Deligiannakis, G., Sakellariou, A. and Vassilakis, E., 2013. The Sparta Fault, Southern Greece: From segmentation and tectonic geomorphology to seismic hazard mapping and time dependent probabilities, Tectonophysics, 597-598, 85-105.

Papazachos, B.C. and Papazachou, C.B., 1997. The earthquakes of Greece, Ziti Publications, Thessaloniki-Greece.

Pentecost, A., 2005. Travertine. Springer-Verlag, Berlin. 